\title{
Dinamika Pengelolaan Ruang Publik Terpadu Ramah Anak: Sebuah Proyek Perkotaan Berkelanjutan?
}

\author{
Paulus Bagus Sugiyono ${ }^{1}$, Raphaella Dewantari Dwianto ${ }^{2}$ \\ Departemen Sosiologi Fakultas IImu Sosial dan IImu Politik Universitas Indonesia ${ }^{1,2}$ \\ Email: paulus.bagus@ui.ac.id ${ }^{1 *}$ \\ ${ }^{*}$ corresponding author
}

\begin{abstract}
Abstrak
Tujuan artikel ini adalah memaparkan historisitas dinamika pengelolaan Ruang Publik Terpadu Ramah Anak (RPTRA) di Jakarta. Artikel ini mengambil pendekatan yang berbeda dengan pendekatan fungsionalis yang umumnya dilakukan untuk menganalisis RPTRA. Upaya ini dilakukan untuk melihat RPTRA bukan sebagai ruang yang "ada" sebagai tempat terjadinya berbagai aktivitas sosial masyarakat, tetapi sebagai ruang yang dibentuk oleh aspek ekonomi, politik, dan budaya. Kerangka konsep yang diambil adalah konsep mengenai ruang dari Henri Lefebvre. Metodologi penelitian yang digunakan adalah pendekatan kualitatif analisis deskriptif, yakni pembacaan literatur dan studi pustaka. Berdasarkan kerangka konsep ruang Lefebvre, dipilih 10 artikel relevan yang kemudian dibaca dan dianalisis. Penelitian ini dilakukan dalam rentang waktu Februari hingga Juni 2021. Temuan penelitian mengemukakan bahwa terdapat tiga disrupsi sosial-politik yang terjadi dalam dinamika pengelolaan RPTRA. Ketiga disrupsi tersebut terkait dengan pengakomodasian aktivitas masyarakat, pergantian kepemimpinan politik, dan pandemi Covid-19. Dengan menggunakan kerangka ruang Lefebvre, penulis berpendapat bahwa seringkali terjadi benturan antara abstraksi perencanaan dan pengelolaan ruang yang dibentuk oleh pemerintah dengan harapan dan ekspektasi masyarakat. Hal yang pertama menggambarkan ruang abstrak, sedangkan hal yang kedua menggambarkan ruang sosial. Demi pengelolaan berkelanjutan, partisipasi masyarakat mesti dilibatkan lagi secara aktif. Dari segi kebijakan, pemerintah perlu mengambil kebijakan politik secara diskretif, bukan demi hegemoni politik semata.
\end{abstract}

Kata kunci : pengelolaan ruang; disrupsi; Lefebvre; ruang publik

\section{Dynamics of Child Friendly Integrated Public Space Management: A Sustainable Urban Project?}

\begin{abstract}
This article aims to explain historical dynamics of RPTRA's management in Jakarta. Notwithstanding common functionalist approach, this article attempts to employ another approach. It tries to portray RPTRA not as a space that "is already there", used by residents to do various activities, but as a space that is dynamically formed by several factors, like economy, politics, and culture. This research is using the concept of space from Henri Lefebvre. This research employs analytic-descriptive qualitative method, such as literature reading. According to the concept of space, I have chosen 10 relevant articles that later be read and analyzed. This research was conducted between February and June 2021. The finding states that there are three socio-political disruptions during the historical dynamics of RPTRA's management. Those related with accommodation of residents' activities, the dynamics of political situation, and Covid-19 pandemic. The Lefebvrian analysis of space shows that there is often friction between city
\end{abstract}

$$
\text { Jurnal Sosiologi Pendidikan Humanis 233|248 }
$$


planning made by government and expectation of residents. The former indicates abstract space, while the latter indicates social space. For the sake of sustainable management, the participation of civil society must be included continuously. Furthermore, government must take political policy discreetly and not for mere political hegemony.

Keywords : production of space; disruption; Lefebvre; public space

\section{LATAR BELAKANG}

Dalam dinamika kehidupan wilayah perkotaan, ruang publik mengambil peran penting dalam membentuk terjadinya perjumpaan dan interaksi antar-individu yang beragam dalam masyarakat. Salah satu ruang publik yang dimaksud adalah taman kota. Bukan hanya menyediakan ruang bagi terwujudnya aspek sosialitas, taman kota juga menyediakan aspek ekologis untuk merekatkan hubungan antara masyarakat perkotaan dengan lingkungan hidup di sekitarnya. Dengan demikian, manusia tidak jatuh ke dalam pendekatan antropologis yang cenderung menempatkan manusia di atas segalagalanya.

Terdapat beberapa kajian yang menekankan tentang aspek sosialitas dan ekologis yang terjadi di taman kota sebagaimana dijelaskan sebelumnya. Jakobcic \& Stokowski (2019) menjelaskan bahwa terkait dengan aspek sosialitas, taman kota dapat mempertemukan masyarakat dari beragam kelompok masyarakat dan latar belakang (connecting across people). Muara dari pertemuan ini adalah terbentuknya komunitas yang inklusif (fostering cross-cultural relationships) melalui pelbagai macam kolaborasi yang terjadi (collaborations creating community) di taman kota. Sementara itu, aspek ekologis terwujud dalam bentuk perjumpaan masyarakat, terutama anak-anak muda, dengan lingkungan hidup (socializing youth). Ada beragam bentuk lingkungan hidup yang dapat dijumpai di taman kota, misalnya pepohonan hijau, tanaman-tanaman, bahkan binatang. Hasil penelitian Jakobcic \& Stokowski (2019) ini sejalan dengan hasil penelitian yang ditemukan oleh Peters (2010) yang mengungkapkan bahwa aspek sosialitas yang terjadi di taman kota mampu menguatkan kohesi sosial yang terjadi dalam masyarakat perkotaan.

Pentingnya taman kota sebagai sebuah ruang publik bagi masyarakat perkotaan, dengan demikian, mendorong terwujudnya pengelolaan taman kota yang baik dan berkelanjutan. Hanya dengan pengelolaan taman kota yang baik dan berkelanjutan, maka masyarakat perkotaan dapat merasakan dampak yang signifikan bagi kehidupan mereka. Dalam hal inilah, Enssle \& Kabisch (2020) menyebut bahwa pengelolaan taman kota yang baik dan berkelanjutan terkait erat dengan bagaimana keadilan (justice) diwujudkan bagi masyarakat perkotaan. Enssle \& Kabisch (2020) sendiri menjabarkan perwujudan keadilan ini ke dalam tiga bentuknya, yakni keadilan distributif (distributive justice), keadilan interaksional (interactional justice), dan keadilan prosedural (procedural justice). Keadilan distributif terkait dengan bagaimana alokasi dan ketersediaan lingkungan hijau wilayah perkotaan dilakukan bagi masyarakat. Hal ini termasuk juga segala bentuk pelayanan yang terkait dengannya, misalnya ketersediaan ruang publik bagi kegiatan rekreatif yang dilakukan oleh masyarakat. Keadilan interaksional merujuk kepada pelayanan terhadap kebutuhan masyarakat yang beragam untuk menikmati lingkungan perkotaan yang inklusif. Bagaimanapun, tidak boleh ada prosedur yang menyeragamkan kebutuhan masyarakat perkotaan terhadap lingkungan tersebut. Sementara itu, keadilan prosedural berarti bahwa masyarakat dilibatkan secara aktif dan partisipatif dalam pengelolaan wilayah perkotaan. Dengan demikian, suara 
mereka dapat didengarkan oleh para pemangku kepentingan yang terkait. Hanya dengan cara inilah, masyarakat perkotaan tidak mengalami eksklusi sosial dari proses pengelolaan perkotaan sebagai ruang tinggal dan hidupnya.

Di dalam konteks Indonesia sendiri, Indonesia, secara khusus DKI Jakarta sebagai ibukota, memiliki konsep taman kota yang khas. Pada tahun 2015, gubernur DKI Jakarta kala itu, Basuki Tjahaja Purnama, menginisiasi sebuah proyek perkotaan yang bernama Ruang Publik Terpadu Ramah Anak (RPTRA). RPTRA adalah salah satu jawaban konkret atas tantangan pembangunan perkotaan yang semakin lama semakin bersifat kapitalis dan mengikis ruang publik, secara khusus ruang bermain dan beraktivitas bagi anak-anak. Beberapa penelitian sebelumnya telah berupaya menganalisis bagaimana RPTRA berperan dan memberikan sumbangsihnya bagi kehidupan masyarakat perkotaan. Penelitian yang dilakukan oleh Aji (2016), misalnya, menunjukkan bahwa RPTRA sebagai salah satu ruang publik masih banyak digunakan oleh masyarakat, terutama mereka yang tinggal di wilayah permukiman padat penduduk. Menurut penelitian Aji (2016), ada tiga faktor signifikan yang memengaruhi keputusan anak-anak untuk mengunjungi RPTRA. Faktor pertama adalah ketersediaan fasilitas bermain. Fasilitas bermain yang sesuai dengan fisik dan psikis anak merupakan perwujudan kebutuhan bagi anak-anak di tengah minimnya ruang bermain bagi mereka. Faktor kedua adalah kemudahan akses untuk mencapai RPTRA. Pembangunan fasilitas yang baik mesti diimbangi dengan kemudahan akses untuk mencapainya. Tanpa akses yang mudah, fasilitas ini akan menjadi sia-sia, sebab tidak dapat digunakan oleh publik dengan baik. Faktor ketiga adalah peran orang tua. Bagaimanapun, orang tua tetap memegang peranan penting dalam keputusan penggunaan RPTRA yang dilakukan oleh anak. Orang tua dapat mengizinkan atau juga turut serta menemani mereka dalam bermain di RPTRA. Oleh sebab itu, ketersediaan fasilitas dan pelayanan bagi orang tua atau orang dewasa di RPTRA juga menjadi hal penting yang tidak boleh dibiarkan begitu saja.

Secara khusus, terkait dengan ruang bermain bagi anak, hasil penelitian Aji (2016) ini sejalan dengan hasil penelitian yang ditemukan oleh Egaratri (2017). Egaratri (2017) melihat bahwa pembangunan perkotaan cenderung meniadakan ruang bermain yang nyaman dan aman bagi anak-anak. Akibatnya, anak-anak yang tinggal di wilayah perkotaan menggunakan ruang yang terbatas untuk bermain. Sayangnya, ruang terbatas ini cenderung berbahaya bagi mereka, misalnya jalan raya dan bangunan yang terbengkalai. Egaratri (2017) menemukan bahwa RPTRA menjadi salah satu alternatif ruang yang nyaman dan aman bagi anak-anak untuk bermain, terutama anak-anak yang berasal dari kelompok masyarakat ekonomi menengah ke bawah yang kesulitan menemukan ruang bermain.

Tidak hanya memiliki fungsi bagi anak-anak saja, RPTRA juga memberikan signifikansinya bagi masyarakat luas yang tinggal di Jakarta. Ada banyak aktivitas yang dapat mereka lakukan di RPTRA sebagai ruang publik di mana masyarakat dari berbagai macam latar belakang dapat hadir tanpa terkecuali. Penelitian Prakoso \& Dewi (2018), misalnya, menemukan bahwa ada berbagai macam aktivitas yang dilakukan oleh mereka yang mengunjungi RPTRA, antara lain bersosialisasi dan bertemu dengan teman, berolahraga, bersantai-santai, bahkan juga melakukan wisata kuliner. Dalam hal ini, tampak bahwa RPTRA memenuhi aspek sosialitas sebagaimana telah dijelaskan oleh Jakobcic \& Stokowski (2019). 
Beberapa penelitian lain memberikan tekanan pada kehadiran RPTRA sebagai sebuah bentuk keberhasilan perubahan wilayah perkotaan menuju ke ruang yang "lebih sehat". Hal ini ditunjukkan oleh penelitian yang dilakukan oleh Sutanto \& Junad (2018). Mengambil studi kasus mengenai RPTRA Kalijodo, Sutanto \& Junad (2018) mengatakan bahwa telah terjadi perubahan pemaknaan sosial atas ruang yang signifikan pada wilayah Kalijodo. Sebelumnya, Kalijodo dinilai oleh masyarakat sebagai wilayah "remang-remang" atau "tidak sehat", karena tingginya tingkat kriminalitas di wilayah tersebut dan adanya bisnis prostitusi yang marak dilakukan. Sesudah pembangunan RTH (Ruang Terbuka Hijau) dan RPTRA Kalijodo, pemaknaan sosial atas Kalijodo mengalami perubahan. Kalijodo menjadi ruang yang lebih "bersahabat" di mana orang tua tidak perlu terlalu khawatir apabila anaknya meminta izin untuk datang dan bermain di wilayah Kalijodo. Salah satu fasilitas yang cukup terkenal di RPTRA Kalijodo dan menjadi tempat berkumpulnya anak-anak muda untuk beraktivitas adalah area bermain skateboard.

Berdasarkan penelitian-penelitian mengenai RPTRA sebagaimana telah dijelaskan sebelumnya ini, penulis melihat bahwa tema besar yang melingkupi penelitian-penelitian tersebut adalah mengenai fungsi sosial yang dapat diberikan oleh RPTRA sebagai sebuah proyek perkotaan. RPTRA dilihat sebagai sebuah ruang yang berdampak terhadap gaya hidup atau pola aktivitas masyarakat perkotaan. Belum ada penelitian yang berupaya untuk melihat bagaimana RPTRA sebagai sebuah ruang itu dibentuk. Bagaimanapun, ruang adalah sebuah wilayah yang bukan hanya membentuk pola interaksi dan aktivitas masyarakat, tetapi juga menjadi perwujudan abstraksi dan pikiran dari masyarakat itu sendiri. Dapat dikatakan bahwa dinamika pembentukan ruang ini tidak hanya terjadi dalam skala mikro, melainkan terjadi dalam skala yang lebih besar atau makro. Dalam hal ini, penelitian mesti dilakukan untuk melihat aspek ekonomi, politik, dan budaya yang berpengaruh terhadap pengelolaan RPTRA yang berkelanjutan.

Artikel ini berusaha untuk melihat dinamika pengelolaan RPTRA dari aspekaspek sebagaimana telah diungkapkan di atas. Secara khusus, artikel ini menganalisis perjalanan historisitas pengelolaan RPTRA di mana aspek ekonomi, politik, dan budaya turut berperan serta. Dampak dari keterlibatan aspek-aspek ini ditunjukkan dari beberapa disrupsi sosial-politik yang hadir dalam dinamika pengelolaan RPTRA selama lima tahun bergulir, terhitung sejak proyek percontohan RPTRA pertama kali dibuat pada tahun 2015. Dalam menganalisis historisitas pengelolaan RPTRA tersebut, artikel ini menggunakan analisis ruang yang ditawarkan oleh Henri Lefebvre, yakni ruang abstrak dan ruang sosial. Artikel ini berfokus pada disrupsi sosial-politik yang muncul dalam dinamika pengelolaan RPTRA di Jakarta. Selanjutnya, penulis mengemukakan refleksi analitis yang dapat diambil demi keberlanjutan pengelolaan RPTRA di masa yang akan datang.

\section{METODE PENELITIAN}

Penelitian ini menggunakan pendekatan kualitatif analisis deskriptif. Metode pengumpulan data yang digunakan adalah penelusuran data sekunder berupa literatur dan studi pustaka dengan menemukan artikel, penelitian, serta tesis yang telah dilakukan sebelumnya, terkait dengan dinamika pengelolaan RPTRA selama lima tahun terakhir, tahun 2016-2020. Pendekatan kualitatif dan metode studi pustaka ini dipilih untuk digunakan, sebab pendekatan dan metode penelitian ini mampu menjawab pertanyaan 
penelitian yang diajukan penulis dengan cara menelusuri kembali secara historis melalui penelitian-penelitian yang telah dilakukan sebelumnya. Pengumpulan datanya sendiri dilakukan dalam rentang waktu Februari hingga Juni 2021. Data-data yang ditemukan dari sumber-sumber tersebut kemudian diolah dan disusun menggunakan paradigma pendekatan konsep ruang Lefebvre untuk menghasilkan sebuah historisitas dinamika pengelolaan RPTRA di Jakarta selama beberapa tahun terakhir. Penggunaan konsep ruang Lefebvre ini memberikan kerangka tersendiri dalam memilih artikel dan penelitian yang relevan. Kerangka yang dimaksud oleh penulis adalah kerangka "tipologi" ekonomi, politik, dan budaya. Dari proses pemilihan dan pemilahan artikel berdasarkan kerangka "tipologi" ini, penulis menggunakan 10 artikel yang terpilih untuk kemudian diolah lebih lanjut. Pengolahan data dilakukan dalam bentuk pembabakan pengelolaan RPTRA yang disebabkan oleh disrupsi-disrupsi yang terkait kerangka "tipologi" tadi. Pembabakan inilah yang kemudian dianalisis dan dipaparkan oleh penulis di bagian hasil. Di bagian akhir, dianalisis mengenai kemungkinan-kemungkinan keberlanjutan pengelolaan RPTRA di masa selanjutnya.

\section{HASIL DAN PEMBAHASAN}

\section{Pengelolaan Ruang dalam Pendekatan Lefebvre}

Sebelum mengungkapkan hasil penelitian, penulis terlebih dahulu memaparkan sedikit mengenai kerangka konsep yang digunakan untuk memilah, memilih, dan menganalisis data-data yang ditemukan. Konsep yang dimaksud adalah konsep ruang dari Henri Lefebvre, seorang sosiolog cum filsuf, sekaligus Marxisme sayap kiri yang berasal dari Prancis. Lefebvre memaknai ruang bukan semata-mata sebagai sebuah tempat terjadinya peristiwa atau aktivitas hidup masyarakat sehari-hari saja. Masyarakat berjumpa, berinteraksi, bekerja sama, atau bisa juga saling berdebat dan berkonflik satu sama lain di sebuah locus tertentu. Dalam arti itu, tentu ruang hanya dilihat secara pasif sebagai sesuatu yang sudah "ada" begitu saja di sana. la menyerupai wadah yang berfungsi sebagai tempat terjadinya aktivitas-aktivitas masyarakat. Lebih daripada itu, Lefebvre memaknai ruang sebagai sesuatu yang lebih dinamis. Ruang bergerak dan terus-menerus mengalami perubahan dari waktu ke waktu. Ruang bersifat lebih lentur, sebab mengalami pembentukan yang dipengaruhi oleh beragam aspek, seperti ekonomi, politik, dan budaya. Dengan demikian, wadah sebagai tempat terjadinya beragam aktivitas itu sendiri sebenarnya mengalami proses pembentukannya. Dalam hal inilah ruang lebih dilihat secara aktif (Gottdiener, 2019).

"Keaktifan" pembentukan ruang ini tentu juga dapat dilihat sebagai sebuah refleksi bahwa ruang bukan hanya mencerminkan tempat terjadinya aktivitas hidup masyarakat, yang dalam titik tertentu membentuk gaya hidup masyarakat tersebut, tetapi juga merupakan hasil dari konstruksi pemikiran masyarakat. Setiap wujud pemikiran dan kontemplasi masyarakat yang beragam membuat masyarakat membentuk ruang yang ada di sekitarnya sesuai dengan apa yang dipikirkan dan dikontemplasikannya tadi. Dengan demikian, ruang merepresentasikan dinamika pemikiran masyarakat yang tinggal di dalamnya.

Dalam proses pembentukan dan pengelolaan ruang dalam masyarakat, Lefebvre melihat adanya kemungkinan terjadinya konflik. Konflik ini pecah ketika ada dua bentuk ruang yang saling berjumpa satu sama lain. Berakar mendalam pada pemikiran Karl Marx dan Max Weber, Lefebvre menganalisis dua bentuk ruang yang saling berkonflik tadi. Ruang yang pertama disebut oleh Lefebvre dengan terminologi "ruang abstrak"

$$
\text { Jurnal Sosiologi Pendidikan Humanis 237 | } 248
$$


(abstract space). Yang dimaksud dengan ruang abstrak adalah konstruksi analitis dan logis mengenai pemetaan dan perencanaan tata ruang dan pengelolaan sebuah wilayah. Konstruksi ini biasanya dibuat oleh pihak pemerintah yang bekerja sama dengan swasta. Dalam beberapa kasus, akademisi juga ikut terlibat dalam proses konstruksi ruang ini. Di dalam ruang inilah, kapitalisme dengan beragam bentuknya mencoba untuk hadir dan menancapkan akar-akarnya ke dalam proses pengelolaan wilayah perkotaan. Perlahan-lahan, setiap jengkal ruang di kota akan diokupasi demi kepentingan keuntungan pemodal dan kroni-kroninya. Untuk mewujudkan hal ini, kerja sama dengan pemerintah dalam berbagai tingkatannya menjadi sesuatu yang perlu dan wajib untuk dilakukan.

Ruang yang kedua adalah "ruang sosial" (social space). Lefebvre menyebut ruang sosial untuk merujuk pada kehidupan sehari-hari (everyday life) yang dijalani oleh masyarakat di sebuah wilayah tertentu. Kehidupan harian ini sifatnya luwes dan mengalir, serta menggambarkan kegairahan masyarakat dalam menjalani kehidupannya. Secara konkret, kehidupan sehari-hari ini misalnya tampak dalam bagaimana anak-anak bermain kejar-kejaran di jalanan, para pedagang yang menjajakan barang-barang yang dijualnya, atau juga orang-orang yang duduk-duduk bersantai sambil menikmati pemandangan sekitar. Di dalam ruang ini, tidak ada sekatsekat yang membatasi bagaimana masyarakat menjalani aktivitas hariannya (Gottdiener, 2019).

Biagi (2020) melihat bahwa pertemuan dalam bentuk konflik di antara kedua ruang ini dapat menimbulkan dua kemungkinan. Kemungkinan pertama adalah keberlanjutan. Sementara itu, kemungkinan kedua adalah ketidakberlanjutan. Apabila segenap pihak yang terlibat dalam proses pengelolaan ruang dapat mengatasi konflik yang terjadi, maka pengelolaan ruang akan menjadi berkelanjutan. Akan selalu ada halhal yang dapat dipelajari dari konflik-konflik yang terjadi. Sedangkan, bila konflik dibiarkan, bukan tidak mungkin pengelolaan menjadi terhenti. Lebih lanjut, Biagi (2020) mengatakan bahwa dua kemungkinan inilah yang membentuk tegangan tersendiri (a strain) dalam proses atau dinamika pengelolaan wilayah perkotaan. Tegangan ini membentuk dua kutub, yakni antara situasi "kematian" (death) atau "keruntuhan" (collapse) kota melawan kesempatan baru (new opportunity) atau "keselamatan" (salvation) keberlanjutan pengelolaan kota.

Dalam memperjuangkan keberlanjutan pengelolaan perkotaan sebagaimana dikatakan Biagi (2020), Purcell (2014) melihat pentingnya partisipasi aktif dari masyarakat. Masyarakat menyuarakan hak mereka, agar pengelolaan perkotaan tidak didominasi oleh negara yang dalam titik tertentu dipengaruhi oleh kapitalisme. Hal inilah yang menjadi salah satu cerminan perwujudan keadilan prosedural sebagaimana diutarakan oleh Enssle \& Kabisch (2020) yang sejalan dengan konsep hak atas kota (right to the city) sebagaimana diusulkan oleh Lefebvre. Pamungkas (2016) memberi catatan bahwa yang dimaksud dengan hak atas kota menurut Lefebvre, dengan demikian, bukan hanya sekadar hak untuk hidup dan tinggal di wilayah perkotaan bagi siapa saja tanpa terkecuali, tetapi juga "hak untuk mengklaim kembali 'sentralitas' atas kota yang memungkinkan kesetaraan."

\section{Disrupsi Sosial-Politik Pertama: Mengakomodasi Semua Aktivitas Masyarakat?}

Selama beberapa tahun berjalan, dinamika pengelolaan RPTRA tidak berjalan lancar begitu saja. Keberlanjutan pengelolaannya selalu terancam dengan kehadiran 
berbagai disrupsi yang datang. Disrupsi-disrupsi ini menganggu "kenyamanan" dan kestabilan pola pengelolaan RPTRA yang saat itu sudah ada dan terjadi. Secara historis, ada beberapa titik-titik disrupsi sosial-politik yang dialami dalam proses pengelolaan RPTRA, sehingga menyebabkan pengelolaan RPTRA tersebut juga harus mengalami adaptasinya tersendiri.

Disrupsi sosial-politik yang pertama tampak terjadi di masa-masa awal perintisan proyek RPTRA di Jakarta. Saat itu, sebagai sebuah proyek yang masih mencari-cari kekuatan fondasi dan pola pengelolaannya, beberapa konflik sosial terjadi. Konflik ini terlihat dalam bentuk penolakan terhadap pembangunan RPTRA di Jakarta yang dianggap tidak membawa daya guna atau bertentangan dengan keinginan masyarakat setempat. Penelitian Surayuda (2016) mencoba menelusuri hal ini. Surayuda (2016) melihat bahwa RPTRA merupakan representasi dari pusat komunitas yang ada di Jakarta. Pusat komunitas di sini berarti bahwa RPTRA dapat menjadi sebuah wadah komunitas di mana masyarakat dapat melakukan pelbagai aktivitas sosial di ruang publik. Meski demikian, permasalahan muncul persis ketika bagaimana aktivitas sosial ini mesti dimaknai. Proyek RPTRA yang baru saja dimulai pembangunannya dihadapkan pada sebuah pertanyaan besar: Apakah RPTRA mengakomodasi setiap aktivitas sosial yang dilakukan oleh masyarakat perkotaan?

Surayuda (2016) secara khusus mengambil studi kasus mengenai RPTRA Kenanga di Cideng. RPTRA Kenanga di Cideng sendiri merupakan salah satu dari enam proyek percontohan yang dibangun di masa-masa awal pembangunan RPTRA di Jakarta. RPTRA ini dipilih oleh Surayuda (2016), karena merepresentasikan permasalahan yang dibawa oleh disrupsi sosial-politik yang pertama ini. Terjadi konflik yang menimbulkan pertentangan pembangunan RPTRA. Terkait dengan pengelolaan RPTRA, pemerintah daerah sendiri mengambil keputusan bahwa RPTRA tidak dapat mengakomodasi semua kegiatan masyarakat. Kegiatan rutin, misalnya administrasi dan perkantoran Rukun Tetangga (RT) dan Rukun Warga (RW), serta penyelenggaraan Pendidikan Anak Usia Dini (PAUD), tidak dapat mengambil tempat pelaksanaan di RPTRA. Surayuda (2016) mengatakan bahwa hal ini tercatat dalam Peraturan Gubernur (Pergub) No.196 tahun 2015 pasal 9 ayat 1 butir a yang berbunyi demikian, "Pelarangan penggunaan RPTRA untuk Sekretariat Rukun Warga/Rukun Tetangga, dikecualikan bagi RPTRA yang sebelumnya sudah ada kantor Sekretariat Rukun Warga/Rukun Tetangga."

Pergub di atas sendiri muncul setelah pembangunan-pembangunan proyek percontohan RPTRA mulai dilakukan. Hal ini tampak dari pengecualian yang tercatat dalam pergub tersebut. Salah satu RPTRA yang dimaksud adalah RPTRA Kenanga di Cideng. Hal ini membuktikan bahwa pergub tersebut hadir sebagai sebuah reaksi atas permasalahan yang dialami dalam proses pembangunan RPTRA yang sudah dimulai, secara khusus mengenai bagaimana aktivitas masyarakat mesti diakomodasi dalam pengelolaan RPTRA. Ada sebuah disrupsi sosial-politik yang terjadi saat itu.

\section{Disrupsi Sosial-Politik Kedua: Pergantian Kepemimpinan Politik}

Pembangunan proyek percontohan RPTRA kemudian diikuti dengan pembangunan-pembangunan RPTRA lainnya di seluruh wilayah administratif di Jakarta. Pada dasarnya, pendekatan yang digunakan dalam pembangunan RPTRA adalah pendekatan kolaboratif yang menggandeng pihak-pihak dari beragam unsur, secara khusus pemerintah (state), swasta (market), dan masyarakat sipil (civil society). Ketiga 
aktor pembangunan ini membentuk relasi triangulasi yang saling terkait satu sama lain selama proses perencanaan dan pembangunan RPTRA (Martinussen, 1999).

Kolaborasi ketiga aktor pembangunan ini ditunjukkan dalam penelitian yang dilakukan oleh Rahmaningtyas \& Rahayu (2019) yang mengambil studi kasus mengenai RPTRA Sungai Bambu, Jakarta Utara. Kolaborasi ini sudah ditunjukkan bahkan sejak dalam masa perencanaan. Selama perencanaan RPTRA Sungai Bambu, Rahmaningtyas \& Rahayu (2019) menemukan keterlibatan pihak-pihak yang terkait. Pihak-pihak itu adalah organisasi Pemberdayaan Kesejahteraan Keluarga (PKK), PT. Jaya Konstruksi dan PT. Arkonin, serta para arsitek dari Universitas Pembangunan Jaya. Tidak lupa, dilakukan pula Focus Group Discussion (FGD) yang melibatkan masyarakat setempat. Melalui FGD ini, masyarakat setempat dapat menyampaikan aspirasi dan pendapatnya mengenai perencanaan RPTRA yang akan dibangun di wilayah mereka tinggal. Dengan demikian, diharapkan bahwa RPTRA yang dibangun nanti dapat memenuhi keinginan dan kebutuhan khas masyarakat tersebut.

Tidak hanya berhenti di tahap perencanaan dan pembangunan, kerja sama ini terus berlanjut di tahap pengelolaan RPTRA sehari-hari. Mengambil studi kasus mengenai RPTRA Kalijodo, Hidayat \& Utari (2018) menemukan bahwa kerja sama antara pemerintah yang direpresentasikan oleh suku dinas (sudin) pariwisata dan suku dinas pendidikan dengan masyarakat sipil yang direpresentasikan oleh organisasi PKK berjalan dengan baik dalam mengelola jalannya program-program di RPTRA sehari-hari.

Meski demikian, pembangunan yang kolaboratif sebagaimana telah dijelaskan di atas ternyata tidak berjalan dengan lancar. Dalam buku yang berjudul Bunga Rampai RPTRA: Kisah Perjalanan Ruang Publik Terpadu Ramah Anak (RPTRA) DKI Jakarta, Permanasari (2020) mengemukakan bahwa terdapat perubahan pendekatan pembangunan RPTRA yang dilakukan di sekitar tahun 2017. Dari pendekatan bottomup, pembangunan menjadi bersifat top-down. Kebijakan ini diambil untuk mempercepat proses pembangunan RPTRA. Tidak heran, pembangunan RPTRA di tahun ini dapat mencapai 100 RPTRA di dalam rentang waktu yang cukup singkat. Permanasari (2020) melihat bahwa percepatan pembangunan dilakukan oleh Djarot Syaiful Hidayat sebagai pelaksana gubernur DKI Jakarta saat itu mengingat masa jabatan pemerintahannya yang akan segera berakhir. Dalam titik tertentu, dapat dikatakan bahwa terdapat kekhawatiran bahwa program RPTRA yang diusung dan diunggulkan oleh pemerintahan Basuki Tjahaja Purnama dan Djarot Syaiful Hidayat tidak lagi menjadi program prioritas pada pemerintahan yang menggantikannya. Hal ini terbukti ketika pemerintahan yang selanjutnya, yakni Anies Baswedan dan Sandiaga Salahudin Uno, tidak melanjutkan program RPTRA, bahkan tidak menganggarkan program RPTRA di dalam Anggaran Pendapatan dan Belanja Daerah (APBD) DKI Jakarta tahun 2017-2022. Pemerintahan yang baru mengusung proyek ruang publik baru lagi yang diberi nama Taman Maju Bersama (TMB). Proyek TMB ini mengundang polemik masyarakat, mengingat secara konseptual, tidak ada perbedaan yang signifikan antara TMB dengan RPTRA. Alih-alih bersifat kritis dan hadir sebagai sebuah pembaruan, penetapan proyek TMB cenderung terlihat sebagai sebuah proyek politis.

Dalam penelitian lainnya, perubahan suasana politik ini juga ditemukan oleh penelitian yang dilakukan oleh Permanasari \& Lientino (2018). Penelitian mereka mengambil studi kasus mengenai perubahan yang dialami oleh wilayah Kalijodo dengan adanya pembangunan RTH dan RPTRA Kalijodo. Meski demikian, di bagian akhir penelitiannya, Permanasari \& Lientino (2018) menemukan bahwa fenomena politik 
dalam bentuk penurunan Basuki Tjahaja Purnama dari kursi gubernur DKI Jakarta akibat kasus penistaan agama berpengaruh terhadap dinamika yang terjadi di RPTRA Kalijodo. Beberapa hal yang dicatat oleh penelitian mereka antara lain kehadiran kembali pedagang ilegal di wilayah RPTRA yang mengganggu kenyamanan pengguna akibat mengambil lahan jogging track, serta hadirnya kembali prostitusi di gubuk-gubuk semi permanen di bawah kolong jembatan.

Dari penjabaran di atas, tampak bahwa disrupsi sosial-politik kedua yang dialami oleh pengelolaan RPTRA adalah mengenai perubahan warna politik yang tercermin melalui pergantian kepemimpinan politik. Bukan hal yang baru lagi di Indonesia bila mengatakan bahwa setiap pergantian kepemimpinan, maka akan ada kebijakankebijakan baru lagi yang dibawanya. Hal ini tidak berarti bahwa kebijakan baru adalah sesuatu yang tidak baik. Kebijakan baru akan membawa dampak baik, selama membawa kritik bagi perbaikan program yang ada sebelumnya. Kebijakan baru tersebut justru akan menjadi kontra produktif dan tidak efisien selama hanya bersifat politis, dalam arti untuk menghilangkan hegemoni politik pemerintahan sebelumnya demi membangun hegemoni politik yang baru.

\section{Disrupsi Sosial-Politik Ketiga: Kemunculan Pandemi "Tidak Terduga" Covid-19}

Disrupsi sosial-politik yang terakhir adalah pandemi Covid-19 yang terjadi di penghujung tahun 2019 dan awal tahun 2020, di mana secara resmi pemerintah Indonesia mengumumkan bahwa kasus pertama pandemi Covid-19 di Indonesia berada pada bulan Maret 2020. Pandemi Covid-19 ini mengubah hampir seluruh gaya hidup masyarakat, tidak terkecuali bagaimana RPTRA sebagai sebuah ruang publik dikelola.

RPTRA sebagai sebuah ruang publik tentu berpotensi mengundang kehadiran masyarakat dengan jumlah yang tidak sedikit di satu tempat atau wilayah tertentu. Keberadaan "kumpulan" masyarakat inilah yang dapat meningkatkan kemungkinan penyebaran pandemi Covid-19. Oleh karena itu, pengelolaan RPTRA berupaya menyesuaikan diri dengan terjadinya pandemi Covid-19. Pada awalnya, pemerintah DKI Jakarta berkeputusan untuk menutup seluruh RPTRA sampai batas waktu yang tidak ditentukan. Setelah pemerintah mampu membuat sebuah protokol kesehatan (prokes) yang memadai, maka mulailah RPTRA ini dibuka dengan menerapkan protokol kesehatan yang ketat. Protokol kesehatan yang dimaksud, antara lain pewajiban penggunaan masker bagi para pengunjung, pengukuran suhu tubuh dengan menggunakan thermo gun, serta penyediaan hand sanitizer atau air dan sabun untuk mencuci tangan di pintu-pintu masuk RPTRA

Untuk melihat bagaimana dinamika pengelolaan RPTRA, secara khusus pelayanan yang diberikan oleh pengelola kepada para pengunjung, selama masa pandemi Covid-19 terjadi, Rustanto \& Akhmad (2020) berupaya melakukan penelitian melalui sudut pandang manajemen dan administrasi. Penelitian mereka menemukan bahwa selama masa pandemi Covid-19, pengelolaan RPTRA lebih menekankan diri pada bagaimana pemeliharaan terhadap fasilitas RPTRA ini dilakukan. Fasilitas yang dimaksud di sini mencakup fasilitas bermain anak-anak, kamar mandi, dan tamantaman, serta pepohonan yang ada di wilayah RPTRA. Para pegawai RPTRA secara rutin menyapu halaman, memotong rumput dan tanaman, serta membersihkan toilet yang ada di RPTRA. Sementara itu, penelitian ini juga menemukan bahwa masyarakat cenderung menginginkan pengelolaan yang lebih daripada itu. Masyarakat berekspektasi bahwa mereka tetap dapat melakukan aktivitas di RPTRA dengan 
protokol kesehatan yang ketat, serta tetap dapat menerima pelayanan yang dilakukan oleh pengelola RPTRA.

Bagan 1. Skema Historis Keberlanjutan Pengelolaan RPTRA

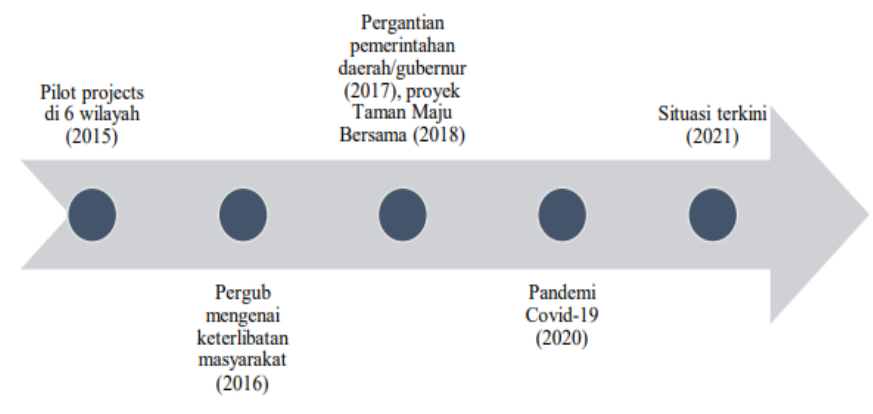

Sumber: Data Olahan Penulis

Terkait dengan pelayanan ini, penelitian Rustanto \& Akhmad (2020) mencatat satu tantangan besar yang masih dialami oleh para pengelola RPTRA. Catatan ini adalah terkait dengan pelayanan yang dilakukan secara digital. Salah satu kebiasaan baru yang secara umum diterapkan selama masa pandemi Covid-19 adalah bagaimana penyelenggaraan suatu acara dapat dilakukan secara digital atau dalam jaringan (daring). Sementara itu, para pengelola RPTRA masih mengalami kesulitan untuk menyelenggarakan pelayanan-pelayanan yang diberikan secara daring (lihat bagan 1).

\section{Melihat Pengelolaan RPTRA melalui Kerangka Pikir Lefebvre}

Disrupsi demi disrupsi melanda dinamika pengelolaan RPTRA yang telah berjalan sejak tahun 2015. Berbagai adaptasi telah dilakukan dalam proses pengelolaan RPTRA selama lima tahun ini. Adaptasi ini dibuat dalam rangka untuk tidak menyerah kalah pada disrupsi sosial-politik yang mengganggu. Atau, dalam bahasa Biagi (2020), adaptasi dilakukan untuk membuka "kesempatan baru" dan menyelamatkan keberlanjutan pengelolaan kota. Melalui kerangka pikir yang ditawarkan oleh Lefebvre, ada beberapa analisis yang setidaknya dapat ditarik dari dinamika pengelolaan RPTRA yang terjadi hingga saat ini di tengah pelbagai disrupsi sosial-politik yang ada.

Pertama, pada dasarnya, RPTRA merupakan salah satu contoh perwujudan ruang sebagai sesuatu yang dinamis. Dalam hal ini, ruang dapat berarti fisik maupun sosial. Kedinamisan ini menjadi perwujudan konkretisasi setiap konsep atau abstraksi yang dipikirkan oleh para pengelola. Dalam kerangka pikir Lefebvre, salah satu indikasi kedinamisan ini tampak dalam bagaimana perubahan-perubahan terjadi dalam dinamika pengelolaan RPTRA ketika menghadapi disrupsi-disrupsi sosial-politik yang ada. Dengan kata lain, dasar pemikiran Lefebvre mendapatkan afirmasinya. Ruang dalam wilayah perkotaan, termasuk RPTRA, bukanlah saja merupakan tempat atau locus yang mewadahi terjadinya aktivitas, tetapi juga merupakan entitas tersendiri yang mengalami pembentukannya yang dinamis, seirama dengan konsep dan abstraksi dari para perencana kota (urban planner).

Bagaimana dasar pemikiran Lefebvre mengenai ruang yang "dinamis" itu terejawantahkan? Dalam disrupsi sosial-politik yang pertama, terdapat suatu perubahan konsep atau abstraksi atas RPTRA yang timbul sebagai reaksi terhadap dinamika sosial 
masyarakat. Saat itu, pemerintah DKI Jakarta menerbitkan pergub yang mengatur tentang pembatasan aktivitas yang dapat dilakukan di wilayah RPTRA. Pembatasan yang dimaksud di antaranya adalah pelarangan kegiatan rutin RT/RW dan PAUD di wilayah RPTRA. Sebelumnya, warga memiliki pandangan tertentu dalam melihat bagaimana ruang dalam wilayah tempat mereka tinggal digunakan. Pembangunan RPTRA, dan terutama pergub yang dikeluarkan, tentu membawa perubahan tersendiri. Ada tembok-tembok pembatas yang dibangun di atas paradigma lama yang dimiliki masyarakat. Dalam hal inilah, ruang menjadi tampak begitu dinamis. Sementara itu, dalam disrupsi sosial-politik yang kedua, pemerintah DKI Jakarta memiliki konsep bahwa pergantian politik akan mengancam keberlangsungan pembangunan RPTRA. Oleh karena itu, pembangunan RPTRA dilakukan secara masif dan cepat. Belum lagi, konsep proyek baru yang ditawarkan oleh pemerintah yang baru mengenai ruang publik dalam bentuk Taman Maju Bersama tentu juga memiliki dampak terhadap bagaimana pengelolaan RPTRA selanjutnya akan dilakukan. Tampak bahwa abstraksi politis turut mengambil andil dalam perubahan kebijakan tata kelola RPTRA. Dalam disrupsi sosialpolitik yang terakhir, untuk menghadapi pandemi Covid-19, konsep utama yang digunakan dalam pengelolaan RPTRA adalah melakukan perawatan fasilitas rutin dan menutup RPTRA bagi publik. Keputusan itu diambil untuk menekan laju penyebaran pandemi. RPTRA, yang tadinya adalah tempat berkumpul masyarakat dari berbagai lapisan, berubah dalam sekejap menjadi sebuah ruang yang sungguh berbeda.

Simpul dari analisis pertama ini terletak pada bagaimana di dalam pengelolaan RPTRA, pemerintah, dalam beragam representasinya, memiliki konsep tertentu yang kemudian dikonkretkan dalam bentuk kebijakan-kebijakan pengelolaan. Hal inilah yang menjadikan RPTRA bukan sekadar sebuah ruang tempat terjadinya aktivitas bagi masyarakat, tetapi juga ruang yang mengalami pembentukan dinamis, akibat kebijakankebijakan tertentu yang diambil oleh pemerintah. Persis di sini, kita diingatkan oleh Lefebvre untuk tidak bersikap naif dalam melihat ruang di perkotaan, termasuk juga pengelolaannya, sebagai sesuatu yang statis. Di balik semua yang tampak secara kasat mata, ada hal-hal yang turut mencengkeram dan memberi pengaruh.

Kedua, kedinamisan ruang itu tidak lahir dari kekosongan. Sebagaimana telah sedikit dijelaskan sebelumnya, Lefebvre berpendapat bahwa kedinamisan pembentukan ruang ini dipengaruhi oleh beragam aspek, termasuk aspek ekonomi, politik, dan budaya. Penulis sendiri berpendapat bahwa kehadiran RPTRA di wilayah Jakarta sebenarnya merupakan salah satu solusi dari pembangunan perkotaan yang cenderung tidak lagi memberi ruang bagi kehidupan publik, melainkan mengokupasinya demi kepentingan privat kapitalisme yang bertujuan untuk mendapatkan keuntungan yang maksimal melalui pembangunan perkotaan (Firman \& Fahmi, 2017). Di tengah karakteristik pembangunan perkotaan yang demikian, kehadiran ruang publik sebagai sebuah wilayah "bersama" yang sungguh dimiliki dan dikelola oleh masyarakat menjadi perwujudan hak atas kota yang paling konkret. Dari sinilah kemudian, perlahan-lahan "perlawanan" atas kapitalisme yang mencengkeram kota dapat dilakukan oleh masyarakat sipil.

Di dalam historisitas pengelolaannya, penulis menemukan bahwa disrupsidisrupsi yang terjadi cenderung diwarnai oleh kepentingan politik dan budaya. Aspek politik, misalnya, tampak betul dalam disrupsi sosial-politik yang pertama dan kedua. Di dalam disrupsi yang pertama, kebijakan untuk tidak memberikan izin bagi penyelenggaraan aktivitas masyarakat yang rutin tentu dilakukan untuk meminimalisir 
perubahan ruang publik menjadi ruang privat yang manfaatnya hanya dapat dirasakan oleh sekelompok orang saja. Sementara itu, dalam disrupsi yang kedua, aspek politik kental terasa, baik dalam percepatan pembangunan RPTRA maupun dalam keberlanjutan pengelolaan RPTRA di tengah kebijakan baru yang diambil oleh pemerintah yang baru. Dalam hal ini, situasi politik ternyata memberikan dampak yang cukup signifikan bagi keberlanjutan pengelolaan RPTRA.

Ketiga, Lefebvre berpendapat bahwa di dalam produksi ruang, terjadi kontestasi antara ruang abstrak (abstract space) dan ruang sosial (social space). Kontestasi yang dibayangkan oleh Lefebvre ini sangat terlihat dalam ketiga disrupsi sosial-politik yang terjadi dalam pengelolaan RPTRA. Misalnya, dalam disrupsi yang pertama, terjadi konflik antara masyarakat sekitar dengan pemerintah setempat ketika RPTRA Kenanga di Cideng hendak dibangun. Surayuda (2016) menyebut konflik antara ruang abstrak dan ruang sosial ini dengan sebutan "kontestasi memori kolektif". Kontestasi memori ini mempertemukan memori masa lampau dan masa kini. Memori masa lampau mencerminkan bagaimana wilayah yang akan dibangun RPTRA itu digunakan oleh masyarakat. Sementara itu, memori masa kini mencerminkan perencanaan pembangunan RPTRA Kenanga. Kontestasi inilah yang akhirnya menimbulkan konflik sosial dalam bentuk penolakan dari pihak warga setempat terhadap pembangunan RPTRA Kenanga di Cideng.

Sementara itu, dalam disrupsi yang lain, dalam pengelolaan RPTRA di masa pandemi Covid-19, Rustanto \& Akhmad (2020) mencatat adanya keinginan-keinginan tertentu yang diharapkan oleh masyarakat terhadap pelayanan RPTRA. Keinginan ini muncul akibat pelayanan RPTRA yang mereka anggap cenderung biasa saja. Adaptasi pemerintah (yang tampak nyata dalam representasi pengelola RPTRA) terhadap pandemi Covid-19 dilakukan hanya sebatas perawatan fasilitas dan penutupan RPTRA. Ketidaksinkronan antara keinginan dan pelayanan ini memang tidak sampai menimbulkan konflik yang berujung pada demonstrasi atau unjuk rasa. Meski demikian, ketidaksinkronan ini merupakan refleksi dari kegelisahan masyarakat yang tidak dapat mewujudkan keinginan mereka mengenai pengelolaan RPTRA yang lebih inovatif.

Apabila dibaca menggunakan skema ruang abstrak dan ruang sosial yang ditawarkan oleh Lefebvre, tampak bahwa selama masa pandemi Covid-19 pemerintah, yang direpresentasikan oleh pengelola RPTRA, hanya "bermain" di wilayah aman dalam mengelola RPTRA. Kebijakan-kebijakan yang dikeluarkan hanya berkisar antara perawatan fasilitas dan pembukaan atau penutupan RPTRA. Kebijakan-kebijakan ini lahir dari "ruang abstrak" yang berbentuk konsep atau pemikiran untuk menjaga RPTRA tetap steril sebagai sebuah ruang publik yang aman dari penyebaran pandemi Covid-19. Hal ini tentu tidak salah. Akan tetapi, tampaknya kebijakan yang dilakukan tidak akan menyentuh "ruang sosial" sebagaimana diharapkan dan dibutuhkan oleh masyarakat.

Keempat, dalam setiap disrupsi sosial-politik yang terjadi dalam pengelolaan RPTRA, terlihat bahwa masyarakat sipil merupakan pihak yang tidak dapat diabaikan begitu saja. Masyarakat sipil punya hak yang tidak dapat diganggu gugat untuk turut serta dalam mengelola wilayah tinggalnya. Inilah yang disebut oleh Lefebvre dengan istilah "hak atas kota" (right to the city). Salah satu "perjuangan" yang dilakukan Lefebvre dalam analisis bagi fenomena perkotaan adalah bagaimana masyarakat tidak lagi mengalami eksklusi sosial dalam proses pengelolaan perkotaan. Dalam hal ini, masyarakat mesti dapat berpartisipasi penuh dalam setiap tata kelola yang dilakukan oleh pemerintah. Sebab, setiap pengelolaan juga akan membawa dampak tertentu bagi 
kehidupan nyata masyarakat. Di dalam ketiga disrupsi sosial-politik yang terjadi, terlihat bahwa apabila pemerintah mengabaikan peran serta masyarakat, maka RPTRA hanya akan menjadi sebuah proyek pemerintahan yang tidak memiliki dampak signifikan lagi bagi kehidupan masyarakat. Masyarakat dapat menolak kebijakan yang diambil ketika merasa bahwa kebijakan tersebut tidak membawa manfaat bagi mereka. Atau, kalaupun tidak menolak, mereka akan bersikap apatis terhadap segala upaya pengelolaan yang dilakukan oleh pemerintah. Hal ini lama kelamaan akan mengikis sense of belonging yang dimiliki oleh masyarakat terhadap ruang-ruang publik yang ada di sekitar mereka.

Sebagai contoh, dalam disrupsi sosial-politik yang pertama, masyarakat sipil menunjukkan penolakan atas pembangunan RPTRA. Hal ini terjadi, karena ada memori tertentu yang tidak bisa begitu saja dihapuskan dari ingatan masyarakat yang tinggal di wilayah tersebut. Masyarakat tidak bisa melupakan begitu saja bahwa wilayah tertentu yang hendak dijadikan wilayah RPTRA dulunya adalah tempat terjadinya aktivitas yang terkait dengan kepengurusan RW dan PAUD. Pengabaian memori dalam bentuk pemaksaan pembangunan akan menimbulkan penolakan masyarakat. Untuk itu, penting untuk mendengarkan bagaimana secara khusus wilayah Kenanga di Cideng dapat dibangun dan dikelola sebagai sebuah RPTRA yang berguna bagi publik. Sementara itu, dalam disrupsi sosial-politik yang terakhir, menjadi sebuah tugas besar dan tidak mudah bagi pengelolaan RPTRA di masa pandemi Covid-19 bukan hanya sekadar untuk merawat fasilitas yang ada di RPTRA, tetapi juga untuk mengakomodasi kebutuhan masyarakat sipil dalam bentuk pelayanan-pelayanan sosial yang dimungkinkan selama masa pandemi Covid-19. Bagaimanapun, situasi yang luar biasa, seperti pandemi Covid-19, selalu membutuhkan penanganan inovatif yang tentu luar biasa pula.

Pentingnya mendengarkan "suara" masyarakat dalam mengelola ruang publik dikemukakan pula dalam penelitian yang dilakukan oleh McKay \& Tantoh (2020). Dalam studi kasus mengenai pengelolaan taman kota Mofolo, di Soweto, Kota Johannesburg, mereka melihat bahwa ada perbedaan concern antara pemerintah, dalam hal ini pengelola taman, dengan masyarakat yang ada di sekitar taman kota. Di satu sisi, pemerintah berkeinginan untuk menambahkan tanaman-tanaman pangan di taman kota. Sementara itu, di sisi lain, masyarakat lebih mementingkan isu mengenai pencemaran air, sampah-sampah yang ada di saluran pembuangan, serta keamanan dan vandalisme yang terjadi di taman kota. Lebih lanjut, McKay \& Tantoh (2020) mengungkapkan bahwa di dalam diskusi-diskusi bersama, pihak pemerintah yang berperan sebagai fasilitator cenderung mendominasi jalannya diskusi. Selain itu, mereka juga melihat bahwa jarang sekali ada pendapat atau saran yang diberikan oleh kelompok masyarakat perempuan di dalam diskusi tersebut. Penelitian mereka menyimpulkan bahwa hanya dengan pendekatan yang sungguh menjunjung aspirasi dan pendapat dari masyarakat sipil, sebuah pengelolaan akan berjalan dengan baik, sebab masyarakat itu sendirilah yang akan menggunakan ruang-ruang publik yang diwacanakan dan dieksekusi melalui kebijakan pemerintah.

\section{Keberlanjutan Pengelolaan RPTRA di Masa yang Akan Datang}

Di tengah disrupsi-disrupsi sosial-politik yang dialami dari mula perencanaan proyek RPTRA hingga pengelolaannya saat ini, pertanyaan reflektif mengenai keberlanjutan pengelolaan tentu menjadi pertanyaan yang bukan hanya penting, tetapi juga relevan untuk terus-menerus dibicarakan. Disrupsi yang terjadi tidak boleh menghentikan apa yang sudah mampu memberikan dampak yang baik bagi kehidupan 
masyarakat perkotaan, terutama mereka yang tinggal di wilayah DKI Jakarta. Belajar dari disrupsi-disrupsi sosial-politik yang terjadi, penulis menawarkan setidaknya dua kunci, agar pengelolaan RPTRA dapat tetap berlanjut dengan baik di masa yang akan datang.

Pertama, masyarakat mesti mengambil peran yang signifikan dalam pengelolaan RPTRA. Di satu sisi, hal ini dapat diwujudkan dengan cara terus-menerus mendengarkan aspirasi dari masyarakat mengenai bagaimana pengelolaan RPTRA mesti dilakukan. Dengan demikian, seperti disampaikan dalam konsep ruang yang ditawarkan oleh Lefebvre, jarak antara ruang abstrak dan ruang sosial dapat dikikis. Di sisi lain, masyarakat bukan hanya didengarkan aspirasinya, tetapi juga dilibatkan partisipasinya secara aktif. Dengan melibatkan partisipasi masyarakat, maka masyarakat berperan serta menjadi aktor pengelola RPTRA. Pelibatan masyarakat ini tentu mesti terus dicari berbagai bentuknya yang inovatif dan solutif, bukan hanya sekadar dengan pelibatan organisasi PKK dalam pengelolaan RPTRA. Bagaimanapun, pelibatan masyarakat dalam pengelolaan RPTRA juga dapat menumbuhkan sebuah rasa kepemilikan (sense of belonging) masyarakat terhadap RPTRA.

Kedua, disrupsi-disrupsi sosial-politik yang terjadi mengajarkan bahwa dalam titik tertentu, aspek politik cenderung memberikan dampak yang signifikan bagi keberlanjutan pengelolaan RPTRA. Kebijakan pengelolaan RPTRA tentu diambil oleh pemerintah setempat. Masalah terjadi ketika pergantian pemerintahan cenderung berdampak juga pada pergantian kebijakan yang juga berdampak besar bagi keberlanjutan pengelolaan RPTRA. Pergantian kebijakan ini akan membawa manfaat sejauh dilakukan dalam rangka memperbaiki kebijakan yang ada sebelumnya. Akan tetapi, kebijakan yang dilakukan semata-mata untuk mengganti hegemoni politik tampaknya cenderung akan berdampak pada ketidakberlanjutan pengelolaan RPTRA. Sudah semestinya hegemoni politik tidak ditempatkan di atas kepentingan masyarakat luas. Untuk itu, kebijakan politik yang diambil terkait dengan pengelolaan RPTRA sungguhlah harus berkaitan dengan RPTRA yang lebih baik itu sendiri.

\section{KESIMPULAN}

Dalam historisitas dinamika pengelolaannya, penulis telah menjabarkan bahwa RPTRA mengalami beberapa disrupsi sosial-politik yang mengancam keberlanjutannya. Disrupsi sosial-politik tersebut berupa pengakomodasian aktivitas masyarakat, pergantian kepemimpinan politik, dan pandemi Covid-19. Beberapa pelajaran penting yang dapat diambil dari proses ini adalah mengenai pelibatan partisipasi masyarakat sipil secara aktif dalam pengelolaan RPTRA. Hal ini terutama dilakukan untuk mengikis jarak antara "ruang sosial" yang dialami oleh masyarakat dengan "ruang abstrak" yang dibentuk dan dikonsepsikan oleh pemerintah atau pengelola RPTRA. Selain itu, pelajaran lain yang juga penting adalah bahwa kebijakan politik sungguh mesti diambil secara diskretif terkait dengan pengelolaan RPTRA yang lebih baik, bukannya sekadar demi kemenangan hegemoni politik. Bagaimanapun, RPTRA adalah sebuah proyek perkotaan yang cenderung telah mampu menghadirkan sebuah ruang publik yang bermanfaat bagi masyarakat perkotaan di tengah pembangunan perkotaan yang diwarnai oleh kapitalisme yang cenderung bertujuan untuk mendapatkan keuntungan. Untuk itu, pengelolaan RPTRA yang berkelanjutan harus menjadi perhatian penting bagi setiap pemangku kepentingan yang terkait. 


\section{PERNYATAAN}

Naskah artikel ini telah dipresentasikan oleh penulis dalam acara Simposium Nasional Jurnal IImu Kesejahteraan Sosial (JIKS) 2.0 Universitas Indonesia pada tanggal 25 Agustus 2021 dalam Sesi Diskusi Panel.

\section{DAFTAR PUSTAKA}

Aji, H. S. (2016). The Development of Child-friendly Integrated Public Space in Settlement Areas as an Infrastructure of Jakarta. WIT Transactions on Ecology and the Environment, 210. doi:10.2495/SDP160021

Biagi, F. (2020). Henri Lefebvre's Urban Critical Theory: Rethinking the City Against Capitalism. International Critical Thought, 10(2), 214-231. https://doi.org/10.1080/21598282.2020.1783693

Egaratri, C. L. (2017). Listening to the Neglected Whispers of Jakarta: Understanding Poor Children's Outdoor Play. The Hague: International Institute of Social Studies.

Enssle, F., \& Kabisch, N. (2020). Urban Green Spaces for the Social Interaction, Health and Well-being of Older People: An Integrated View of Urban Ecosystem Services and Socio-environmental Justice. Environmental Science and Policy, 109, 36-44. https://doi.org/10.1016/j.envsci.2020.04.008

Firman, T., \& Fahmi, F. Z. (2017). The Privatization of Metropolitan Jakarta's (Jabodetabek) Urban Fringes: The Early Stages of 'Post-Suburbanization' in Indonesia. Journal of the American Planning Association, 83(1), 68-79. https://doi.org/10.1080/01944363.2016.1249010

Gottdiener, M. (2019). The New Urban Sociology. Routledge.

Hidayat, R., \& Utari, A. S. (2018). Dari Krisis Ruang Publik ke Kemitraan Intersektoral: Studi Kasus di RPTRA Kalijodo, Jakarta. Jurnal Sosial Humaniora, 11(2), 82-94. http://dx.doi.org/10.12962/j24433527.v0i0.4309

Jakobcic, Y. L., \& Stokowski, P. A. (2019). The Role of Regional Park Districts in Strengthening Community Relationships. Journal of Park and Recreation Administration, 37(3), 19-3. https://web.s.ebscohost.com/abstract?direct=true \&profile=ehost\&scope=site \&auth type $=$ crawler \&jrnl $=07351968 \& A N=138334221 \& \mathrm{~h}=\mathrm{J} 7 \mathrm{HLX} 8 \mathrm{hPNv0HbLHzPartFp} \% 2$ FhhBmLqREWX7mAo2QcEv5ibAJ\%2B1TrUsLhYT4\%2FvRcAYGf3wHKL1tyQbLx 24SfuSGA\%3D\%3D\&crl=c\&resultNs=AdminWebAuth\&resultLocal=ErrCrINotAuth \&crlhashurl=login.aspx\%3Fdirect\%3Dtrue\%26profile\%3Dehost\%26scope\%3Dsite \%26authtype\%3Dcrawler\%26jrnl\%3D07351968\%26AN\%3D138334221

Martinussen, J. (1999). Society, State, and Market: A Guide of Competing Theories of Development. Fernwood Publishing.

McKay, T. J. M., \& Tantoh, H. B. (2020). A Dialogue Approach to Stakeholder Engagement within Urban Communities: The Case of Mofolo Park, Soweto, Johannesburg, South Africa. Journal of Environmental Planning and Management. doi: 10.1080/09640568.2020.1862769.

Pamungkas, A. S. (2016). Produksi Ruang dan Revolusi Kaum Urban menurut Henri Lefebvre.

Permanasari, E. (2020). Bunga Rampai RPTRA: Kisah Perjalanan Ruang Publik Terpadu Ramah Anak (RPTRA) DKI Jakarta. UPJ Press.

Permanasari, E., \& Lientino, T. (2018). Transformasi Makna dan Fungsi Ruang di RPTRA Kalijodo dalam Pergulatan Citra Kota Jakarta. Jurnal RUAS, 16(2), 13-27. http://dx.doi.org/10.21776/ub.ruas.2018.016.02.2

Peters, K. (2010). Social Interactions in Urban Parks: Stimulating Social Cohesion? Urban Forestry \& Urban Greening, 9(2). https://doi.org/10.1016/j.ufug.2009.11.003

Prakoso, S., \& Dewi, J. (2018). Child-friendly Integrated Public Spaces (RPTRA): Uses and Sense of Attachment. IOP Conf. Ser.: Earth Environ.

Purcell, M. (2014). Possible Words: Henri Lefebvre and the Right to the City. Journal of 
Urban Affairs, 36(1), 141-154. https://doi.org/10.1111/juaf.12034

Rahmaningtyas, I., \& Rahayu, A. Y. S. (2019). Collaborative Governance in Providing Facilities of Sungai Bambu Child Friendly Integrated Public Space, North Jakarta City. IOP Conf. Series: Earth. Environ.

Rustanto, A. E., \& Akhmad, J. (2020). RPTRA Activities Program in Services to the Community during the Covid-19 Pandemic. Proceedings of the 1st Annual International ConConference on Natural and Social Science Education (ICNSSE 2020).

Surayuda, R. J. (2016). Pusat Komunitas dan Kontestasi Memori Kolektif: Studi Kasus Ruang Publik Terpadu Ramah Anak (RPTRA) Kenanga di Cideng, Jakarta Pusat. MASYARAKAT: Jurnal Sosiologi, 21(2), 233-261. https://doi.org/10.7454/mjs.v21i2.5097

Sutanto, E., \& Junad, P. (2018). Kalijodo Transformation in Establishment of Healthy Environment in Jakarta. IOP Conf. Ser.: Earth Environ. 